\title{
CHLORINE-BASED PLASMA ETCHING OF GaN Ge.
}

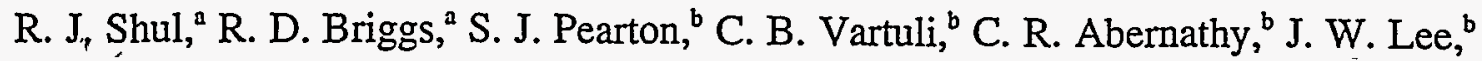 \\ C. Constantine, ${ }^{c}$ and C. Baratt ${ }^{\mathrm{c}}$

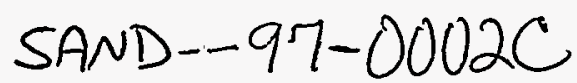

aSandia National Laboratories, Albuquerque, NM 87185-0603

bUniversity of Florida, Department of Materials Science and Engineering, Gainesville, FL 32611

'Plasma-Therm, Inc., St. Petersburg, FL 33716

$$
\text { CONF-96/202--5) }
$$

\section{ABSTRACT}

The wide band gap group-III nitride materials continue to generate interest in the semicondu $\mathbb{R}_{\mathrm{r}} \mathrm{S}$ T I community with the fabrication of green, blue, and ultraviolet light emitting diodes (LEDs), blue lasers, and high temperature transistors. Realization of more advanced devices requires pattern transfer processes which are well controlled, smooth, highly anisotropic and have etch rates exceeding $0.5 \mu \mathrm{m} / \mathrm{min}$. The utilization of high-density chlorine-based plasmas including electron cyclotron resonance (ECR) and inductively coupled plasma (ICP) systems has resulted in improved $\mathrm{GaN}$ etch quality over more conventional reactive ion etch (RIE) systems.

\section{INTRODUCTION}

Interest in $\mathrm{GaN}$ and related group-III nitride materials continues to grow as demonstrations of blue, green, and UV LEDs, blue lasers, and high temperature transistors are reported..$^{1-9}$ Commercially available LEDs and advances in device fabrication may be attributed to recent progress in material growth technology. Although further improvements in material properties can be expected, enhanced device performance can only be obtained with improved process capabilities including dry etching. Laser facet fabrication is especially dependent upon dry etch pattern transfer since the majority of epitaxially grown group-III nitrides is on sapphire substrates which inhibits cleaving the sample with reasonable yield.

The importance of dry etch development for the group-III nitrides is further accentuated by the fact that they resist etching in standard, room temperature wet chemical etchants. These materials are chemically inert and have strong bond energies as compared to other compound semiconductors. GaN has a bond energy of $8.92 \mathrm{eV} /$ atom, InN $7.72 \mathrm{eV} /$ atom, and AlN 11.52 $\mathrm{eV} /$ atom as compared to GaAs which has a bond energy of $6.52 \mathrm{eV} /$ atom. Therefore, essentially all device patterning has been accomplished using dry etching technology. For example, commercially available LEDs from Nichia are fabricated using a $\mathrm{Cl}_{2}$-based reactive ion etch (RIE) to expose the n-layer of the heterostructure. ${ }^{3}$ Also, the first GaN-based laser diode was fabricated using RIE to form the laser facets. ${ }^{4}$ The etched sidewalls were somewhat rough and may have contributed to scattering loss and a high lasing threshold, thus demonstrating the need for improved dry etch processes.

With the recent emphasis placed on the development of dry etch processes for the group-III nitrides, perhaps the most crucial advancement has been the utilization of high-density plasmas. Plasma etching of $\mathrm{GaN}$ has been reported using several dry etch techniques including RIE, electron cyclotron resonance (ECR), inductively coupled plasma (ICP), magnetron reactive ion etch (MRIE), and chemically assisted ion beam etching (CAIBE). Using RIE, GaN etch rates as high as $650 \AA / m i n$ have been reported at dc-biases of $-400 \mathrm{~V} \cdot{ }^{10-13}$ Under similar dc-bias conditions, high-density plasmas and ion beam etch systems typically yield higher etch rates than RIE etches due to ion densities which are 2 to 4 orders of magnitude greater. Etch profiles also tend to be more anisotropic due to lower process pressures which results in less collisional scattering of the plasma species. GaN etch rates have been reported up to $1.3 \mu \mathrm{m} / \mathrm{min}$ at $-150 \mathrm{~V}$ dc-bias in an ECR, ${ }^{14-22} 3500 \AA / m i n$ at $-100 \mathrm{~V}$ dc-bias in a MRIE, $2300 \AA / m i n$ at $-500 \mathrm{~V}$ in a CAIBE, ${ }^{24}$ and $6875 \AA / \mathrm{min}$ at $-280 \mathrm{~V}$ dc-bias in an ICP. ${ }^{25,26} \mathrm{GaN}$ has also been etched using low energy electron

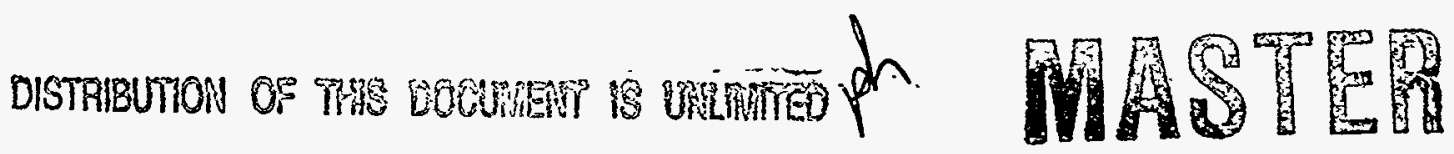




\section{DISCLAIMER}

Portions of this document may be illegible in electronic image products. Images are produced from the best available original document. 


\section{DISCLAIMER}

This report was prepared as an account of work sponsored by an agency of the United States Government. Neither the United States Government nor any agency thereof, nor any of their employees, make any warranty, express or implied, or assumes any legal liability or responsibility for the accuracy, completeness, or usefulness of any information, apparatus, product, or process disclosed, or represents that its use would not infringe privately owned rights. Reference herein to any specific commercial product, process, or service by trade name, trademark, manufacturer, or otherwise does not necessarily constitute or imply its endorsement, recommendation, or favoring by the United States Government or any agency thereof. The views and opinions of authors expressed herein do not necessar. ily state or reflect those of the United States Government or any agency thereof. 
enhanced etching ( $\mathrm{LE} 4$ ) at $\sim 2500 \AA / \mathrm{min}$ in $\mathrm{Cl}_{2}$ at $100^{\circ} \mathrm{C}$ and $0 \mathrm{~V}$ dc-bias. ${ }^{27}$ In this paper, we compare ECR and ICP etch results for $\mathrm{GaN}$ in $\mathrm{Cl}_{2}$ - and $\mathrm{BCl}_{3}$-based plasmas. $\mathrm{GaN}$ etch rates obtained in an ECR and ICP will also be compared to RIE results in several plasma chemistries.

\section{EXPERIMENT}

The GaN films etched in this study were grown by one of three techniques; metal organicmolecular beam epitaxy (MO-MBE), radio-frequency-MBE (If-MBE), or metal organic chemical vapor deposition (MOCVD). The MO-MBE GaN films were grown at $925^{\circ} \mathrm{C}$ on either $\mathrm{GaAs}$ or $\mathrm{Al}_{2} \mathrm{O}_{3}$ substrates in an Intevac Gen II system described previously. ${ }^{28}$ The group-III source was triethylgallium and the atomic nitrogen was formed in an ECR Wavemat source operating at $200 \mathrm{~W}$ forward power. The rf-MBE GaN film was grown in a commercial MBE system equipped with a conventional $\mathrm{Ga}$ effusion cell and a rf plasma source to supply atomic nitrogen during growth. The epitaxial layers were grown on a $\mathrm{n}^{+} \mathrm{GaAs}$ substrate. After deposition of a $5000 \AA \mathrm{Sn}$-doped GaAs buffer layer, growth was interrupted while the substrate temperature was stabilized at $620^{\circ} \mathrm{C}$. The GaN epi-layer was comprised primarily of the cubic phase. The MOCVD GaN film was approximately $1.8 \mu \mathrm{m}$ thick and was grown on a c-plane sapphire substrate in a multiwafer rotating disk reactor at $1040^{\circ} \mathrm{C}$ with a $20 \mathrm{~nm} \mathrm{GaN} \mathrm{buffer} \mathrm{layer} \mathrm{grown} \mathrm{at} 530^{\circ} \mathrm{C} .^{29}$

The ECR plasma reactor used in this study was a load-locked Plasma-Therm SLR 770 etch system with a low profile Astex 4400 ECR source in which the upper magnet was operated at 165 A. Energetic ion bombardment was provided by superimposing an $\mathrm{rf}$-bias $(13.56 \mathrm{MHz})$ on the sample. Etch gases were introduced through an annular ring into the chamber just below the quartz window. To minimize field divergence and to optimize plasma uniformity and ion density across the chamber, an external secondary collimating magnet was located on the same plane as the sample and was run at $25 \mathrm{~A}$. Plasma uniformity was further enhanced by a series of external permanent rare-earth magnets located between the microwave cavity and the sample.

ICP etching offers an attractive alternative high-density dry etching technique. The general belief is that ICP sources are easier to scale-up than ECR sources and are more economical in terms of cost and power requirements. ICP does not require the electromagnets or waveguiding technology necessary in ECR. Additionally, automatic tuning technology is much more advanced for if plasmas than for microwave discharges. ICP plasmas are formed in a dielectric vessel encircled by an inductive coil into which rf-power is applied. A strong magnetic field is induced in the center of the chamber which generates a high-density plasma due to the circular region of the electric field that exists concentric to the coil. At low pressures ( $\leq 10 \mathrm{mTorr}$ ), the plasma diffuses from the generation region and drifts to the substrate at relatively low ion energy. Thus, ICP etching is expected to produce low damage while achieving high etch rates. Anisotropic profiles are obtained by superimposing a rf-bias on the sample to independently control ion energy. In order to study ICP, the ECR source and chamber were removed from the SLR 770 etch system and replaced with a Plasma-Therm ICP source. The ICP reactor used in this study was a cylindrical coil configuration with an alumina vessel encircled by a three-turn inductive coil into which $2 \mathrm{MHz}$ rf-power was applied. Identical to the ECR, energetic ion bombardment was provided by superimposing an rf-bias $(13.56 \mathrm{MHz})$ on the sample and etch gases were introduced through an annular region at the top of the chamber. The RIE plasma used in this study was generated by a $13.56 \mathrm{MHz}$ rf-power supply in the ECR chamber configuration discussed above with the ECR source power turned off.

All samples were mounted using vacuum grease on an anodized $\mathrm{Al}$ carrier that was clamped to the cathode and cooled with He gas. Samples were patterned using AZ 4330 photoresist. Etch rates were calculated from the depth of etched features measured with a Dektak stylus profilometer after the photoresist was removed with an acetone spray. Each sample was approximately $1 \mathrm{~cm}^{2}$ and depth measurements were taken at a minimum of three positions. Standard deviation of the etch depth across the sample was nominally less than $\pm 10 \%$ with run-to-run variation less than \pm $10 \%$. The gas phase chemistry for several plasmas was studied using a quadrupole mass spectrometer (QMS) or an optical emission spectrometer (OES). Surface morphology, anisotropy, and sidewall undercutting were evaluated with a scanning electron microscope (SEM). The rootmean-square (rms) surface roughness was quantified using a Digital Instruments Dimension 3000 
atomic force microscope (AFM) system operating in tapping mode with Si tips. Auger electron spectroscopy (AES) was used to investigate the near-surface stoichiometry of GaN before and after exposure to several plasmas.

\section{RESULTS AND DISCUSSIONS}

Chlorine-based plasmas have been the dominant etch chemistries used for $\mathrm{GaN}$ and compound semiconductors in general due to the higher volatility of the group-III chlorides as compared to the other halogen-based plasmas. Table I shows possible etch products and their boiling points for $\mathrm{GaN}$ etched in a variety of halogen- and hydrocarbon-based plasma chemistries. In a Cl-based plasma, the high volatility of $\mathrm{GaCl}_{3}$ and the nitrogen based etch products implies that the etch rates are not limited by desorption of the etch products. However, due to the strong bond energies of the group-III nitrides, the initial bond breaking of the GaN which must precede the etch product formation may be the rate limiting step. ${ }^{30}$ Faster GaN etch rates obtained in high-density plasma etch systems (ECR, ICP, and MRIE) as compared to RIE may be attributed to a two step process directly related to the plasma flux. Initially the high-density plasmas increase the bond breaking mechanism allowing the etch products to form and then produce efficient sputter desorption of the etch products. This can be seen in Figure 1 where $\mathrm{GaN}$ etch rates are plotted as a function of rfpower for ECR, ICP, and RIE discharges. Plasma etch conditions were; 1 mTorr pressure, 10 sccm $\mathrm{Cl}_{2}, 15 \mathrm{sccm} \mathrm{H} \mathrm{H}_{2}, 3 \mathrm{sccm} \mathrm{CH}_{4}, 10 \mathrm{sccm} \mathrm{Ar}, 1000 \mathrm{~W}$ ECR power, and $500 \mathrm{~W}$ ICP power. The lowest rf-power required to generate a stable RIE plasma was $50 \mathrm{~W}$, whereas both ECR and ICP plasmas were stable at $1 \mathrm{~W}$ rf-power. Independent of etch technique, the $\mathrm{GaN}$ etch rate increased as the rf-power or ion energy increased due to improved sputter desorption of the etch products. The ECR and ICP GaN etch rates were approximately 5 to 10 times faster than those obtained in the RIE mode due to higher plasma densities resulting in more efficient $\mathrm{GaN}$ bond breaking followed by enhanced sputter desorption of the etch products. The etched surface morphology was evaluated and quantified using AFM as a function of plasma etch technique. The rms roughness measured for samples exposed to the plasmas were normalized to the rms roughness for the as-grown samples since different $\mathrm{GaN}$ samples were used in the etch matrix. The normalized rms roughness remained relatively constant and smooth $(<\sim 3 \mathrm{~nm})$ independent of ion energy and etch platform.

\begin{tabular}{c|c}
\hline Etch Products & Boiling Point $\left({ }^{\circ} \mathrm{C}\right)$ \\
\hline $\mathrm{GaCl}_{3}$ & 201 \\
\hline $\mathrm{GaF}_{3}$ & $\sim 1000$ \\
\hline $\mathrm{GaBr}_{3}$ & 279 \\
\hline $\mathrm{GaI}_{3}$ & sub 345 \\
\hline$\left(\mathrm{CH}_{3}\right)_{3} \mathrm{Ga}$ & 55.7 \\
\hline & \\
\hline $\mathrm{NCl}_{3}$ & $<71$ \\
\hline $\mathrm{NF}_{3}$ & -129 \\
\hline $\mathrm{NBr}_{3}$ & \\
\hline $\mathrm{NI}_{3}$ & explodes \\
\hline $\mathrm{NH}_{3}$ & -33 \\
\hline $\mathrm{N}_{2}$ & -196 \\
\hline$\left(\mathrm{CH}_{3}\right)_{3} \mathrm{~N}$ & -33 \\
\hline
\end{tabular}

Table I. Boiling points of possible GaN etch products for halogen and hydrocarbon based plasma chemistries. 


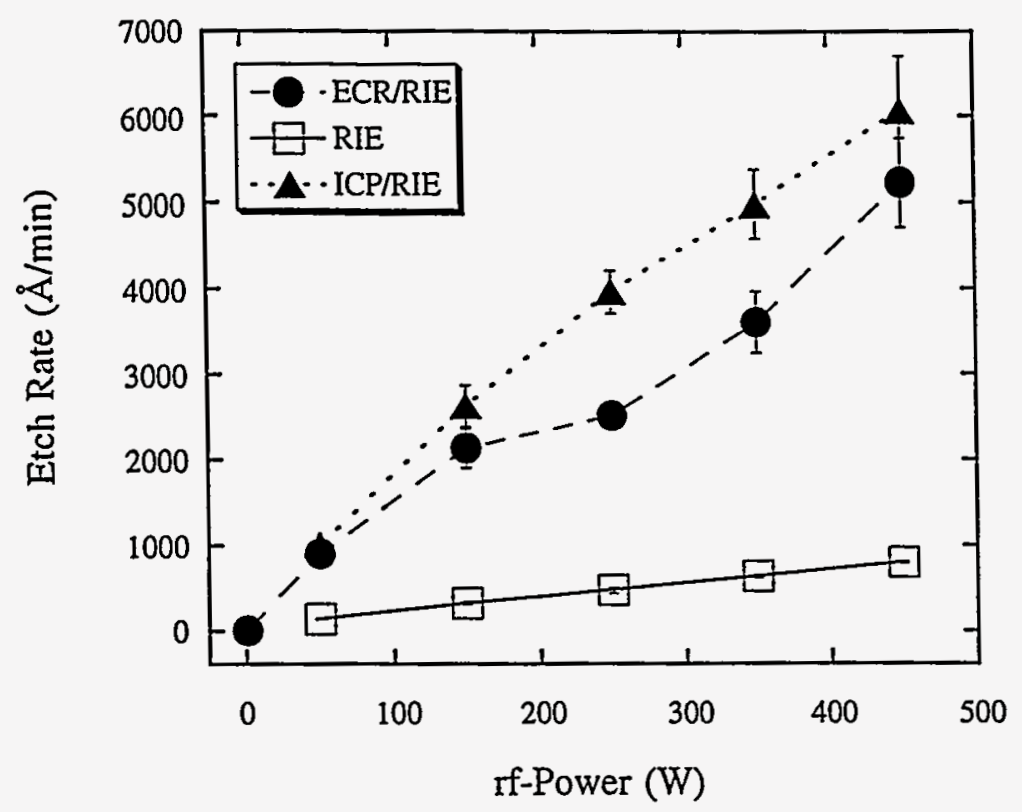

Figure 1. GaN etch rates as a function of rf-power as etched in ECR-, ICP-, and RIE-generated $\mathrm{Cl}_{2} / \mathrm{H}_{2} / \mathrm{CH}_{4} / \mathrm{Ar}$ plasmas.

Chlorine-based discharges usually produce fast etch rates and smooth surface morphologies for compound semiconductors whereas $\mathrm{CH}_{4} / \mathrm{H}_{2}$-based plasma chemistries typical result in smooth etch morphologies at much slower rates. This is unexpected based on the information in Table 1 where the volatility of the $\mathrm{Ga}\left(\mathrm{CH}_{3}\right)_{3}$ etch product is much higher than that for $\mathrm{GaCl}_{3}$. This demonstrates the complexity of the etch process where redeposition, polymer formation, or gas-phase kinetics can have a significant impact on the etch rates. An example is shown in Figure 2 where $\mathrm{GaN}$ etch rates are plotted as a function of rf-power for $\mathrm{Cl}_{2} / \mathrm{Ar}$ and $\mathrm{CH}_{4} / \mathrm{H}_{2} / \mathrm{Ar}$ ECR- and RIE-generated

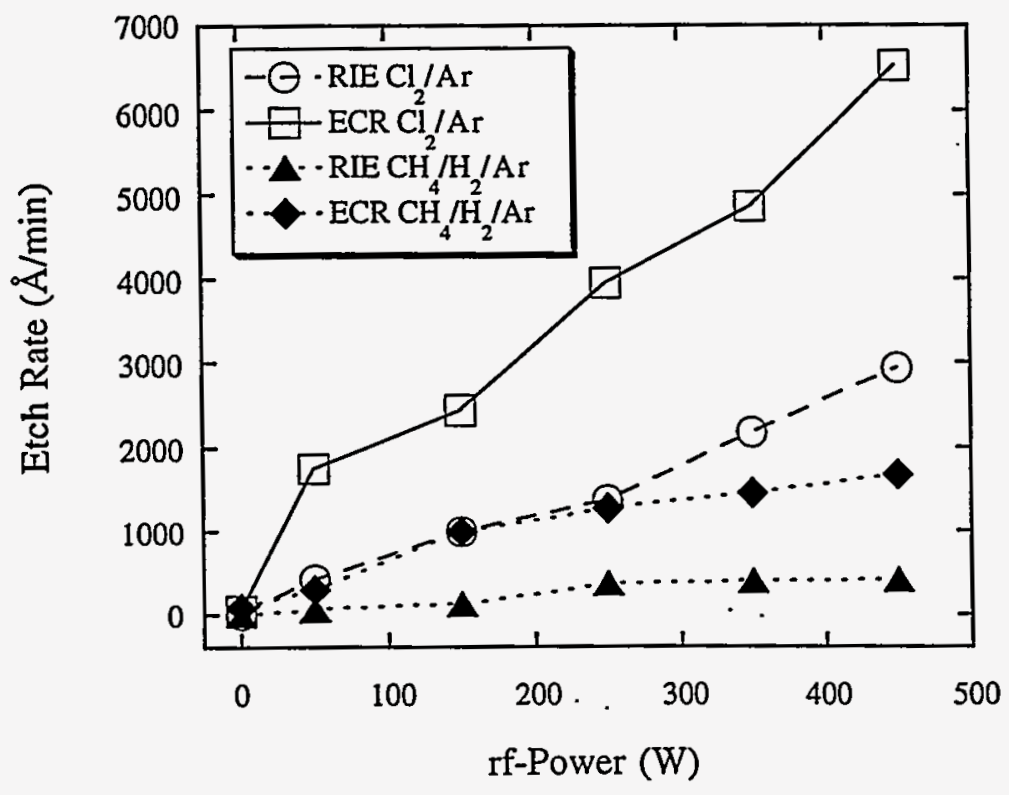

Figure 2. $\mathrm{GaN}$ etch rates as a function of rf-Power for ECR- and RIE-generated $\mathrm{Cl}_{2} / \mathrm{Ar}$ and $\mathrm{CH}_{4} / \mathrm{H}_{2} / \mathrm{Ar}$ plasmas. 
plasmas. These experiments were performed in the same chamber with either 1000 or $0 \mathrm{~W}$ of applied ECR power. The pressure was held constant at $1.5 \mathrm{mTorr}$ and the plasma chemistry was 5 $\mathrm{sccm} \mathrm{Cl} 2 / 10 \mathrm{sccm}$ Ar or $5 \mathrm{sccm} \mathrm{CH}_{4} / 15 \mathrm{sccm} \mathrm{H_{2 }} / 10 \mathrm{sccm}$ Ar. GaN etch rates were significantly faster in $\mathrm{Cl}_{2} / \mathrm{Ar}$ possibly due to more efficient sputter desorption of the $\mathrm{GaCl}_{3}$ etch products as compared to $\mathrm{Ga}\left(\mathrm{CH}_{3}\right)_{3} \cdot \mathrm{CH}_{4} / \mathrm{H}_{2}$ plasmas may also initiate redeposition or polymer formation on the etched surfaces thereby reducing the etch rates. Faster GaN etch rates in the high-density ECR were attributed to enhanced $\mathrm{GaN}$ bond breaking and sputter desorption of the etch products.

Although fast GaN etch rates have been observed in chlorine-based plasmas, the source of reactive $\mathrm{Cl}$ as well as the use of additive gases have not been discussed. Unless otherwise noted, the following plasma conditions remained constant: ECR; $1 \mathrm{mTorr}, 850 \mathrm{~W}$ ECR power, $150 \mathrm{~W}$ ifPower with corresponding dc-biases of -170 to $-210 \mathrm{~V}$, and $30 \mathrm{sccm}$ total flow with $5 \mathrm{sccm}$ Ar and ICP; 2 mTorr, $500 \mathrm{~W}$ ICP power, 95 to $115 \mathrm{~W}$ rf-Power with a constant dc-bias of $-250 \pm 10 \mathrm{~V}$, and $30 \mathrm{sccm}$ total flow with $5 \mathrm{sccm}$ Ar. Samples etched in the ECR were grown by MO-MBE whereas samples etched in the ICP were grown by MOCVD. In Figure 3, GaN etch rates are shown as a function of $\% \mathrm{H}_{2}$ concentration for ECR- and ICP-generated $\mathrm{Cl}_{2} / \mathrm{H}_{2} / \mathrm{Ar}$ plasmas. GaN etch rates in the ECR and ICP increased slightly as $\mathrm{H}_{2}$ was initially added to the $\mathrm{Cl}_{2} / \mathrm{Ar}$ plasma $\left(10 \% \mathrm{H}_{2}\right)$ implying a reactant limited regime. Using quadrupole mass spectrometry (QMS) in the ECR discharge, the $\mathrm{Cl}$ concentration (indicated by m/e $=35$ peak intensity) remained relatively constant at $10 \% \mathrm{H}_{2}$. As the $\mathrm{H}_{2}$ concentration was increased further, the $\mathrm{Cl}$ concentration decreased and the $\mathrm{HCl}$ concentration increased as the $\mathrm{GaN}$ etch rates decreased in both plasmas, presumably due to the consumption of reactive $\mathrm{Cl}$ by hydrogen. In Figure 4, the rms roughness is plotted as a function of $\% \mathrm{H}_{2}$ for the ECR and ICP plasmas. The rms roughness for the as-grown GaN samples etched in the ECR was $6.4 \pm 0.5 \mathrm{~nm}$ and $3.5 \pm 0.2 \mathrm{~nm}$ for samples etched in the ICP. The rms roughness for $\mathrm{GaN}$ etched in the ECR increased as the $\% \mathrm{H}_{2}$ increased from 0 to 10 and then decreased as the $\mathrm{H}_{2}$ concentration was increased further. The roughest surface was observed at $10 \% \mathrm{H}_{2}$ where the etch rate was greatest. The rms-roughness for samples etched in the ICP were less than $1 \mathrm{~nm}$ except for the pure $\mathrm{Cl}_{2}$ plasma where the rms roughness was $41 \mathrm{~nm}$.

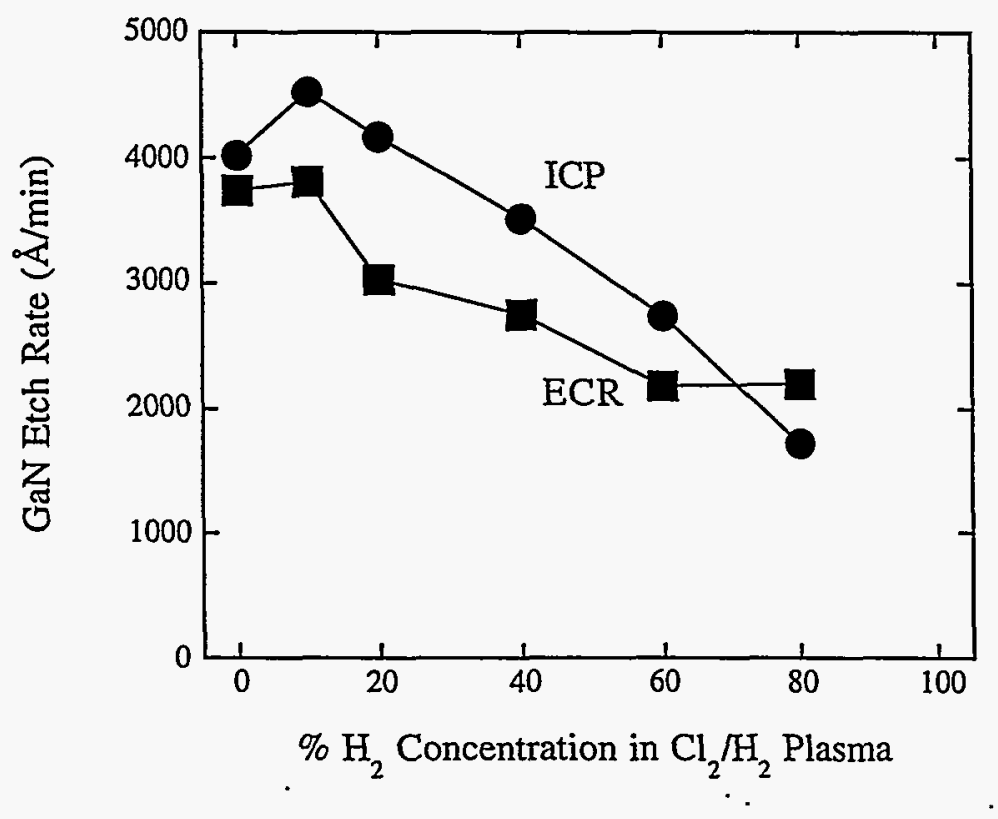

Figure 3. $\mathrm{GaN}$ etch rates as a function of $\% \mathrm{H}_{2}$ for $\mathrm{ECR}$ - and ICP-generated $\mathrm{Cl}_{2} / \mathrm{H}_{2} / \mathrm{Ar}$ plasmas. 


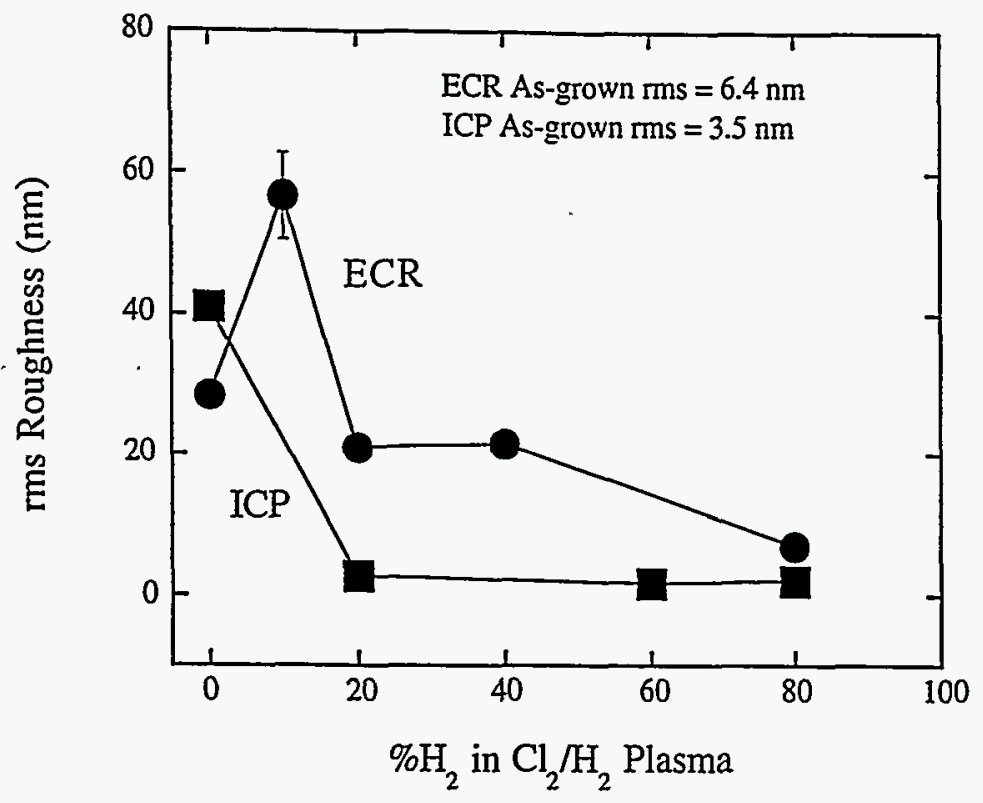

Figure 4. GaN rms-roughness as a function of $\% \mathrm{H}_{2}$ for $\mathrm{ECR}$ - and ICP-generated $\mathrm{Cl}_{2} / \mathrm{H}_{2} / \mathrm{Ar}$ plasmas.

$\mathrm{GaN}$ etch profiles showed a strong dependence on the $\% \mathrm{H}_{2}$ in the $\mathrm{Cl}_{2} / \mathrm{H}_{2} / \mathrm{Ar}$ ECR plasma (Figures $5 \mathrm{a}-\mathrm{c}$ ). The etched surface was quite rough (Figure $5 \mathrm{a}$ ) in the $\mathrm{Cl}_{2} / \mathrm{Ar}$ plasma possibly due to preferential removal of the $\mathrm{GaCl}_{3}$ etch products or micromasking of the surface. The foot observed at the edge of the etched feature may be attributed to mask-edge erosion due to the aggressive attack of photoresist by reactive $\mathrm{Cl}$. As the $\mathrm{H}_{2}$ concentration was increased to $20 \%$, the etch became smooth and very anisotropic (Figure 5b). However, the SEM micrograph showed a lower density of surface roughness near the etched feature than AFM images scanned in open $10 \mathrm{x}$ $10 \mu \mathrm{m}$ areas. This may be attributed to a proximity effect of the etch where redeposition or micromasking was worse in open areas. It may also explain the smooth etch observed in Figure $5 \mathrm{~b}$ where the rms roughness measured in the field was approximately $21 \mathrm{~nm}$. At $60 \% \mathrm{H}_{2}$, the etch remained smooth and anisotropic with a slight foot at the base of the feature (Figure 5c). For GaN samples etched in the $\mathrm{Cl}_{2} / \mathrm{H}_{2} / \mathrm{Ar}$ ICP-generated plasma (Figures $5 \mathrm{~d}-\mathrm{f}$ ), the features were anisotropic and smooth independent of $\% \mathrm{H}_{2}$. Smooth $\mathrm{GaN}$ etched surfaces were observed in a pure $\mathrm{Cl}_{2}$ ICP plasma (Figure 5d) where the rms-roughness was $\sim 40 \mathrm{~nm}$ possibly due to proximity effects.

In Figure 6, $\mathrm{BCl}_{3}$ was substituted for $\mathrm{Cl}_{2}$ and was used to etch $\mathrm{GaN}$ in both the ECR and ICP reactor. The increase in etch rate observed at $10 \% \mathrm{H}_{2}$ concentration in the ECR-generated $\mathrm{BCl}_{3}$ plasma correlated with an increase in the reactive $\mathrm{Cl}$ concentration as observed by QMS. As the $\mathrm{H}_{2}$ concentration was increased further, the $\mathrm{Cl}$ concentration decreased, the $\mathrm{HCl}$ concentration increased, and the $\mathrm{GaN}$ etch rates decreased due to the consumption of reactive $\mathrm{Cl}$ by hydrogen. In the ICP reactor the $\mathrm{GaN}$ etch rates were quite slow and decreased as hydrogen was added to the plasma up to $80 \% \mathrm{H}_{2}$ where a slight increase was observed. The $\mathrm{GaN}$ etch rates were consistently faster in the $\mathrm{Cl}_{2}$-based plasmas as compared to $\mathrm{BCl}_{3}$ due to the generation of higher concentrations of reactive $\mathrm{Cl}$.

In Figure 7, GaN etch rates are shown for ECR-generated $\mathrm{Cl}_{2} / \mathrm{SF}_{6} / \mathrm{Ar}$ and $\mathrm{BCl}_{3} / \mathrm{SF}_{6} / \mathrm{Ar}$ plasmas as a function of \% $\mathrm{SF}_{6}$. With the substitution of $\mathrm{SF}_{6}$ for $\mathrm{H}_{2}$ in the $\mathrm{Cl}_{2}$-based plasma, the $\mathrm{GaN}$ etch rates were typically a factor of 2 slower. As the concentration of $\mathrm{SF}_{6}$ was increased, the etch rate decreased up to $30 \% \mathrm{SF}_{6}$ followed by a slight increase at $40 \%$. As the $\% \mathrm{SF}_{6}$ was increased from 0 to 20, the $\mathrm{Cl}$ concentration $(\mathrm{m} / \mathrm{e}=35)$ decreased but remained significant; faster $\mathrm{GaN}$ etching at $20 \% \mathrm{SF}_{6}$ might be expected based on the $\mathrm{Cl}$ concentration alone. However, formation of SCl $(\mathrm{m} / \mathrm{e}=67)$ was observed at $20 \% \mathrm{SF}_{6}$ which may be responsible for the reduced $\mathrm{GaN}$ etch rate due to consumption of the reactive $\mathrm{Cl}$ by $\mathrm{S}$. At 30 and $40 \% \mathrm{SF}_{6}$, the $\mathrm{Cl}$ 


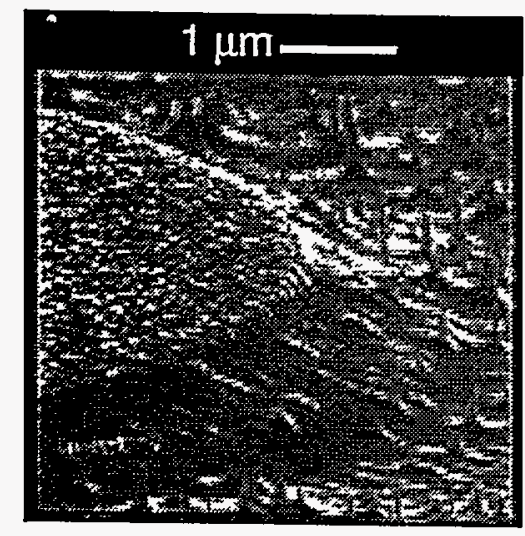

ECR

(a)

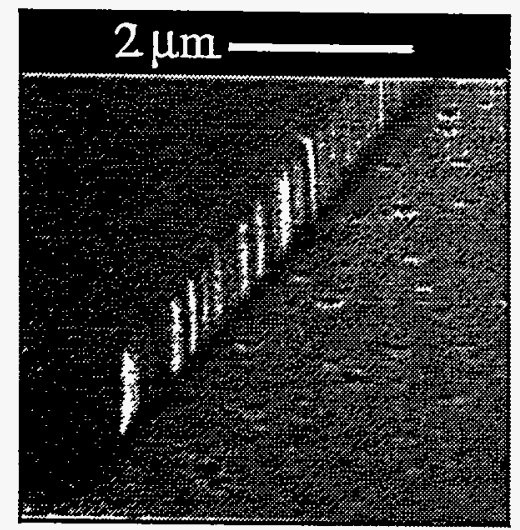

ICP (d)

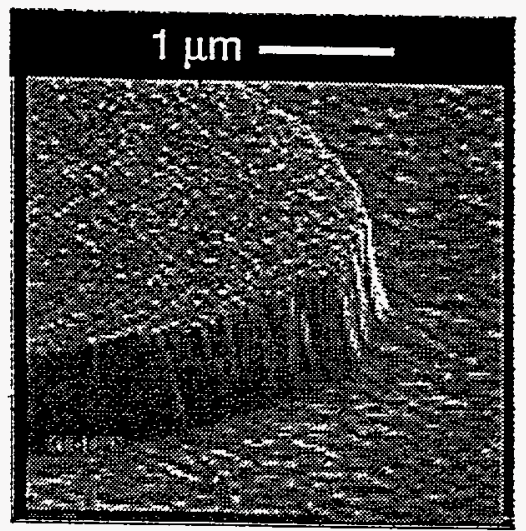

(b)

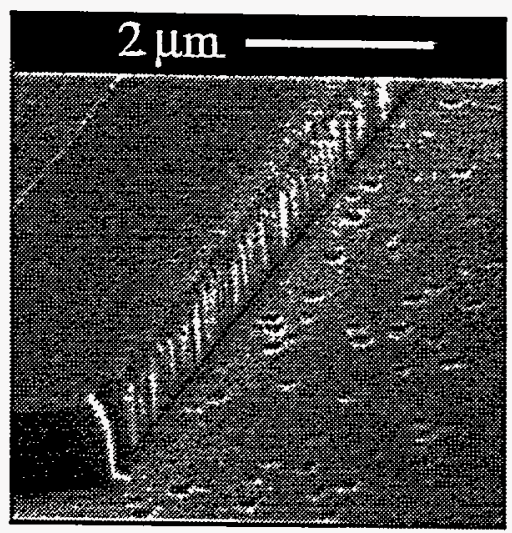

(e)

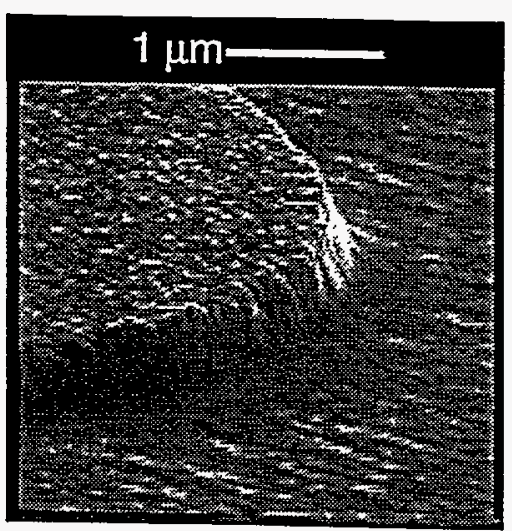

(c)

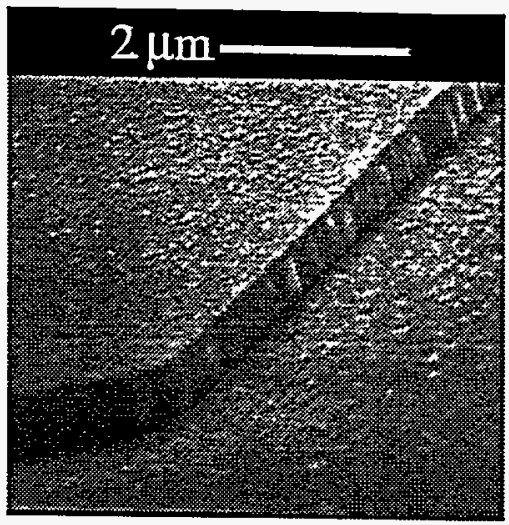

(f)

Figure 5. SEM micrographs of $\mathrm{GaN}$ samples etched in either an ECR or ICP $\mathrm{Cl}_{2} / \mathrm{H}_{2} / \mathrm{Ar}$ plasma at (a, d) $0 \% \mathrm{H}_{2}$, (b, e) $20 \% \mathrm{H}_{2}$, and (c, f) $60 \% \mathrm{H}_{2}$. The photoresist mask has been removed.

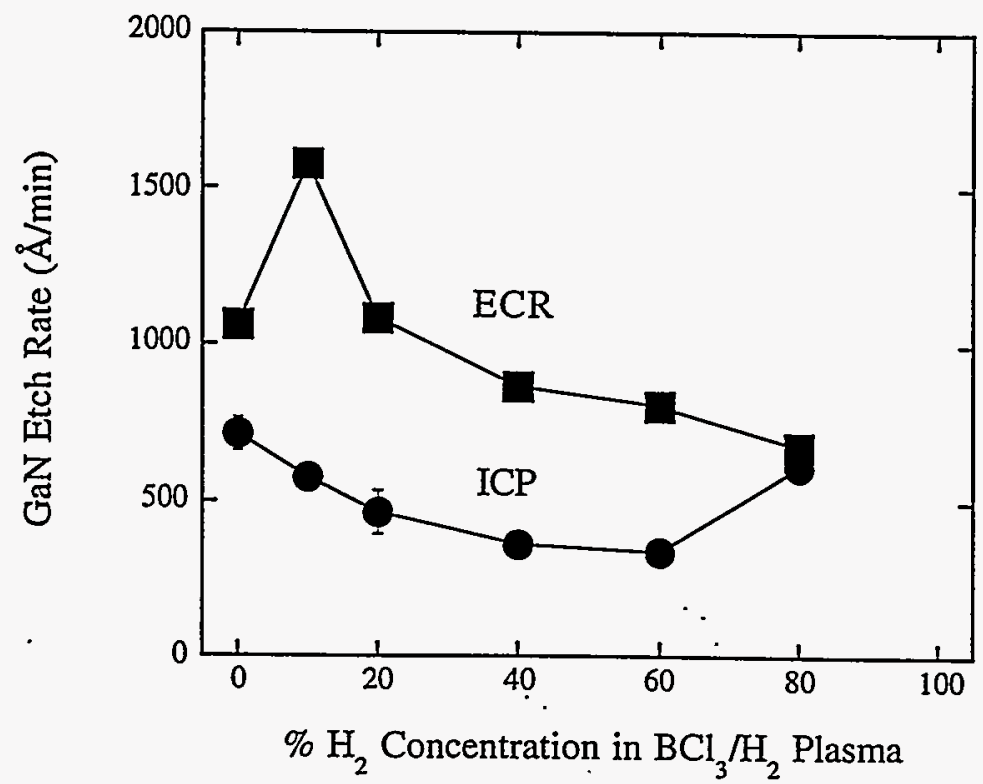

Figure 6. GaN etch rates as a function of $\% \mathrm{H}_{2}$ for $\mathrm{ECR}$ - and ICP-generated $\mathrm{BCl}_{3} / \mathrm{H}_{2} / \mathrm{Ar}$ plasmas. 


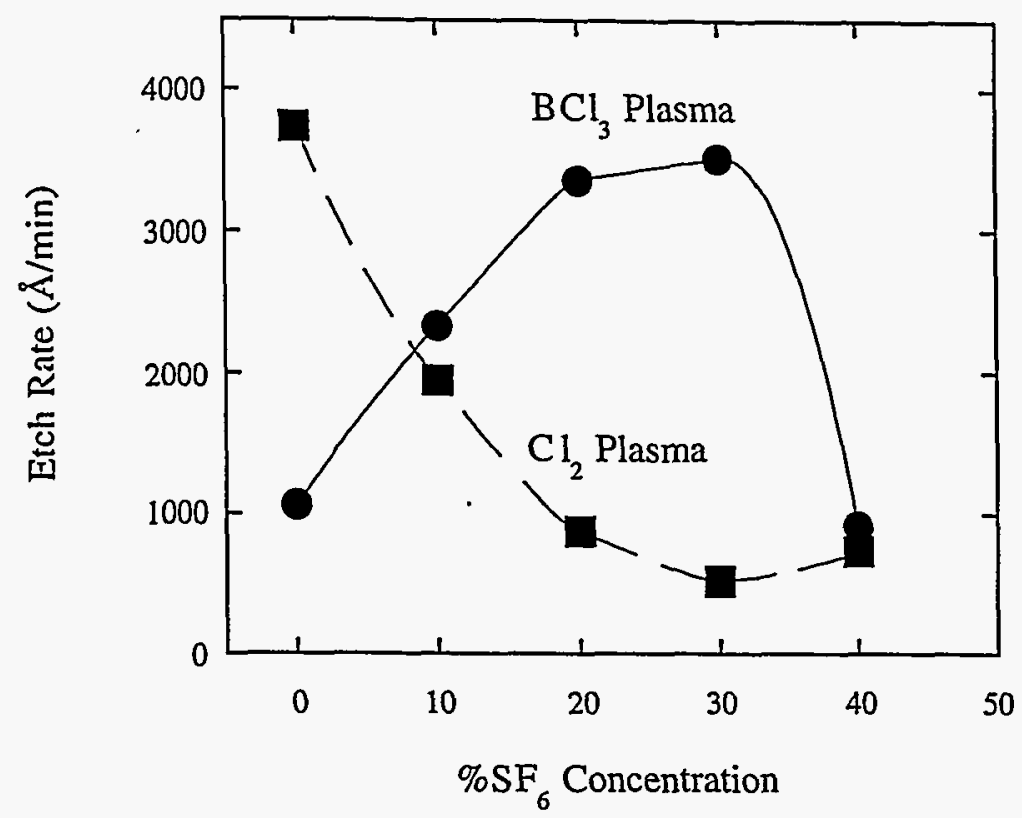

Figure 7. GaN etch rates as a function of $\% \mathrm{SF}_{6}$ concentration for $\mathrm{Cl}_{2} / \mathrm{SF}_{6} / \mathrm{Ar}$ and $\mathrm{BCl}_{3} / \mathrm{SF}_{6} / \mathrm{Ar}$ plasmas.

concentration was greatly reduced and slow $\mathrm{GaN}$ etch rates resulted. The opposite trend was observed for $\mathrm{BCl}_{3}$, where the $\mathrm{GaN}$ etch rates were significantly greater when $\mathrm{SF}_{6}$ was substituted for $\mathrm{H}_{2}$. The $\mathrm{GaN}$ etch rate increased up to $30 \% \mathrm{SF}_{6}$ and then decreased sharply at $40 \% \mathrm{SF}_{6}$. The $\mathrm{Cl}$ concentration $(\mathrm{m} / \mathrm{e}=35)$ also increased as the $\mathrm{SF}_{6}$ increased to $30 \%$ and then decreased at $40 \%$. As with the $\mathrm{Cl}_{2}$-based plasma, there appeared to be a competitive reaction of sulfur with chlorine as the $\mathrm{SCl}$ concentration increased above $30 \% \mathrm{SF}_{6}$. Under most etch conditions, the trend of the $\mathrm{Cl}$ concentration correlated with the trends observed for the $\mathrm{GaN}$ etch rates.

Auger spectra were taken to determine the near-surface stoichiometry of $\mathrm{GaN}$ following exposure to ECR-generated $\mathrm{Cl}_{2} / \mathrm{H}_{2} / \mathrm{Ar}, \mathrm{Cl}_{2} / \mathrm{SF}_{6} / \mathrm{Ar}, \mathrm{BCl}_{3} / \mathrm{H}_{2} / \mathrm{Ar}$, and $\mathrm{BCl}_{3} / \mathrm{SF}_{6} / \mathrm{Ar}$ plasmas. The Auger spectrum for the as-grown $\mathrm{GaN}$ showed a $\mathrm{Ga}: \mathrm{N}$ ratio of 1.5 with normal amounts of adventitious carbon and native oxide on the $\mathrm{GaN}$ surface. In general, the $\mathrm{Ga}: \mathrm{N}$ ratio increased as the $\% \mathrm{H}_{2}$ or $\% \mathrm{SF}_{6}$ concentration increased in either $\mathrm{BCl}_{3}$ or $\mathrm{Cl}_{2}$. These trends implied that the $\mathrm{GaN}$ film was being depleted of $\mathrm{N}$ perhaps due to preferential chemical etching of the $\mathrm{N}$ atoms with the addition of $\mathrm{H}_{2}$ or $\mathrm{SF}_{6}$ to the plasma.

In the ICP reactor, $\mathrm{GaN}$ etch rates were obtained for $\mathrm{Cl}_{2} / \mathrm{N}_{2} / \mathrm{Ar}$ and $\mathrm{BCl}_{3} / \mathrm{N}_{2} / \mathrm{Ar}$ plasmas. Figure 8 shows the $\mathrm{GaN}$ etch rates as a function of $\% \mathrm{~N}_{2}$ concentration in both $\mathrm{Cl}_{2}$ and $\mathrm{BCl}_{3}$. As the $\% \mathrm{~N}_{2}$ concentration increased in the $\mathrm{Cl}_{2}$ plasmas, the $\mathrm{GaN}$ etch rates decreased due to less available reactive $\mathrm{Cl}$. However, in the $\mathrm{BCl}_{3}$ plasmas the $\mathrm{GaN}$ etch rates increased significantly up to $40 \% \mathrm{~N}_{2}$ and then decreased as more $\mathrm{N}_{2}$ was added. This trend is similar to that observed in ECR and ICP etching of GaAs, GaP, and In-containing materials. ${ }^{31,}{ }^{32}$ Ren et al. observed peak etch rates for In-containing materials in an ECR plasma at $75 \% \mathrm{BCl}_{3}-25 \% \mathrm{~N}_{2}$. As $\mathrm{N}_{2}$ was added to the $\mathrm{BCl}_{3}$ plasma, Ren observed maximum emission intensity for atomic and molecular $\mathrm{Cl}$ at $75 \%$ $\mathrm{BCl}_{3}$ using OES. Correspondingly, the $\mathrm{BCl}_{3}$ intensity decreased and a $\mathrm{BN}$ emission line appeared. It was suggested that $\mathrm{N}_{2}$ enhanced the dissociation of $\mathrm{BCl}_{3}$ resulting in higher concentrations of reactive $\mathrm{Cl}$ and $\mathrm{Cl}$ ions and higher etch rates. This may explain the faster $\mathrm{GaN}$ etch rates observed from 20 to $60 \% \mathrm{~N}_{2}$ in $\mathrm{BCl}_{3} / \mathrm{Ar}$ in this study, however higher concentrations of reactive $\mathrm{Cl}$ and $\mathrm{BN}$ emission were not observed using OES in the ICP. 


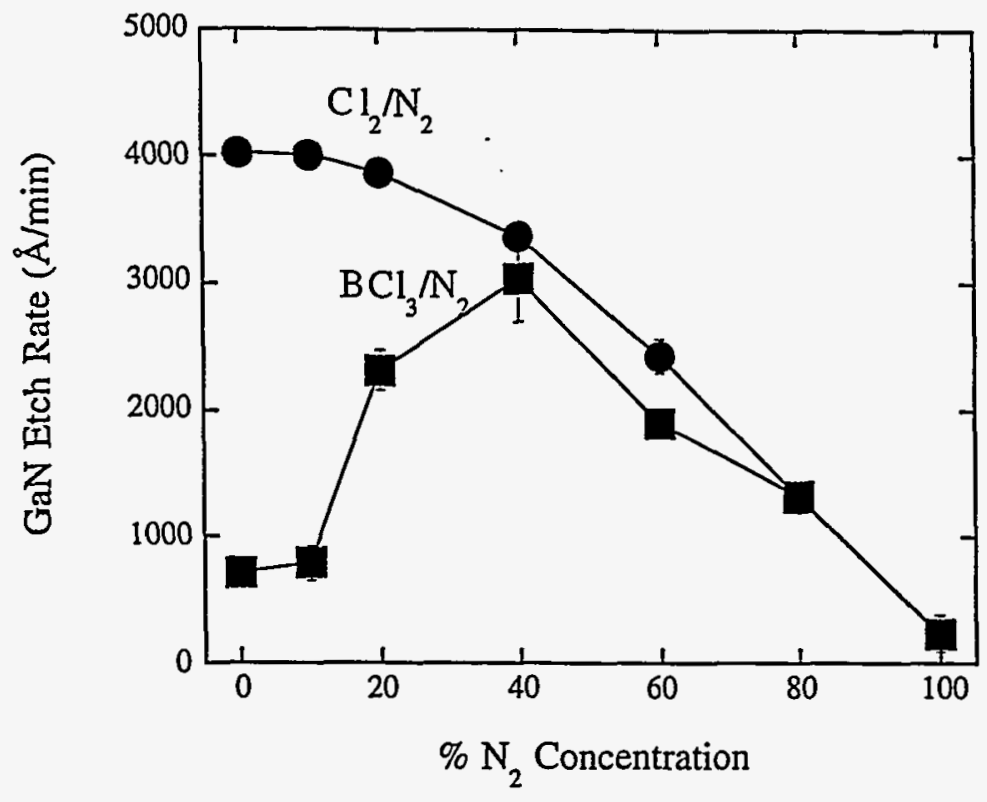

Figure 8. GaN etch rates as a function of $\% \mathrm{~N}_{2}$ concentration for $\mathrm{Cl}_{2} / \mathrm{N}_{2} / \mathrm{Ar}$ and $\mathrm{BCl}_{3} / \mathrm{N}_{2} / \mathrm{Ar}$ ICPgenerated plasmas.

Additional halogen-containing plasmas have been used to etch GaN including $\mathrm{ICl} / \mathrm{Ar}$ and IBr/Ar. In Figure 9, GaN etch rates are shown as a function of rf-Power in an ECR plasma. Etch conditions were; 1.5 mTorr pressure, $1000 \mathrm{~W}$ ECR power, $4 \mathrm{sccm} \mathrm{ICl/RBr}$, and $4 \mathrm{sccm}$ Ar. The $\mathrm{GaN}$ etch rates increased with increasing If-Power (sputter desorption) at similar rates up to 150 $\mathrm{W}$, however at $250 \mathrm{~W}$ rf-power, the $\mathrm{GaN}$ etch rate in ICl/Ar increased to $>1.3 \mu \mathrm{m} / \mathrm{min}$ whereas the $\mathrm{Br}$ etch rate decreased slightly. This is the fastest etch rate reported to date for GaN. Nearsurface Auger electron spectroscopy (AES) showed no loss of $\mathrm{N}$ in the Ga:N ratio at low

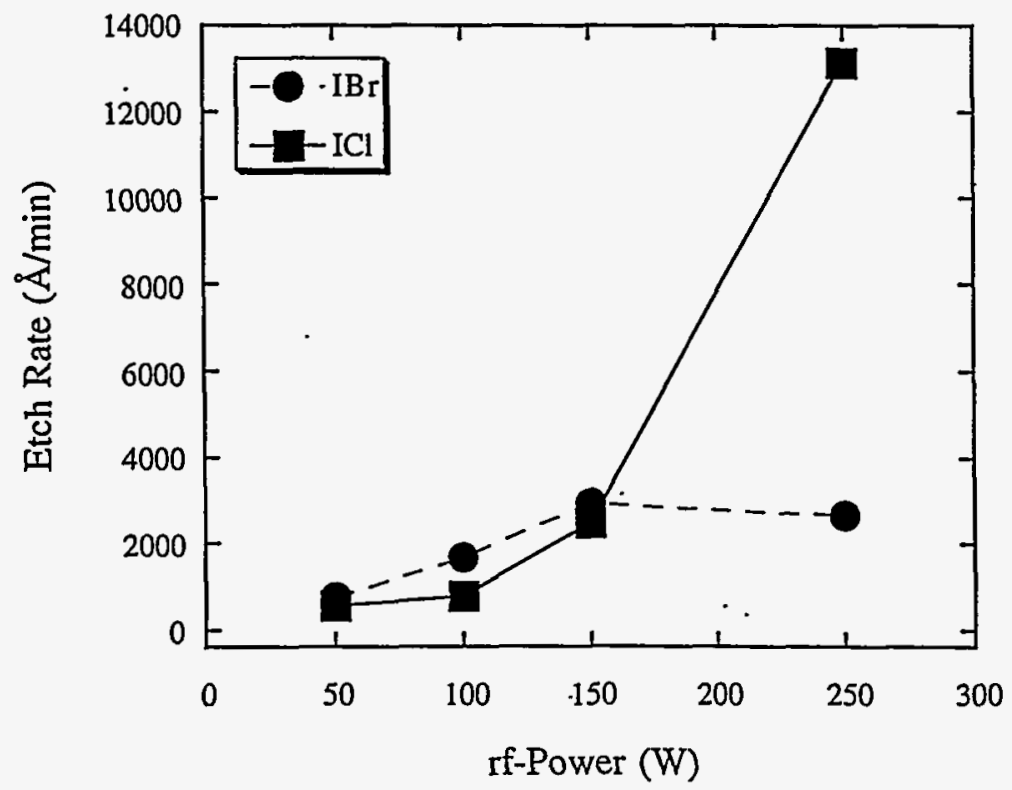

Figure 9. GaN etch rate as a function of rf-Power for ECR- and RIE-generated $\mathrm{ICl} / \mathrm{Ar}$ and $\mathrm{BBr} / \mathrm{Ar}$ plasmas. 
rf-powers. The high volatility of the $\mathrm{GaI}_{3}$ etch products may have increased the chemical etch mechanism of the $\mathrm{Ga}$ and thereby minimized preferential loss of the lighter $\mathrm{N}$ atoms maintaining the stoichiometry of the as-grown film. ${ }^{14,15}$

Since several GaN samples were used in this study, it is important to identify any etch dependence on growth technique. In Figure 10, GaN ECR etch rates are shown as a function of rf- power for samples grown by MO-MBE, rf-MBE, and MOCVD. The ECR plasma conditions were; $2 \mathrm{mTorr}$ pressure, $22.5 \mathrm{sccm} \mathrm{Cl}_{2}, 2.5 \mathrm{sccm} \mathrm{H}, 5 \mathrm{sccm} \mathrm{Ar}, 30^{\circ} \mathrm{C}$ electrode temperature, $1000 \mathrm{~W}$ microwave power, and rf-powers ranging from 1 to $450 \mathrm{~W}$ with a corresponding dc-bias range of -25 to $-275 \pm 25 \mathrm{~V}$ : GaN samples were etched simultaneously. As the rf-power was increased the $\mathrm{GaN}$ etch rates increased due to higher ion energies and improved sputter desorption efficiency, independent of growth technique. Etch rates approaching $9000 \AA / \mathrm{min}$ were obtained for the MO-MBE and rf-MBE GaN samples at $450 \mathrm{~W}$ rf-power ( $-275 \mathrm{~V}$ dc-bias). We observed a trend where the MO-MBE GaN etched faster than the if-MBE GaN which was faster than the MOCVD GaN. Faster etch rates correlated with higher rms roughness for the as-grown GaN samples. The rms-roughness for the as-grown GaN samples were $19.38 \pm 0.44 \mathrm{~nm}$ for MOMBE, $3.12 \pm 0.84 \mathrm{~nm}$ for $\mathrm{rf}-\mathrm{MBE}$, and $1.76 \pm 0.29 \mathrm{~nm}$ for MOCVD.

Figure 11 shows a SEM micrograph of MOCVD grown GaN etched in a $\mathrm{Cl}_{2} / \mathrm{H}_{2} / \mathrm{Ar}$ ICPgenerated plasma. The $\mathrm{GaN}$ was overetched by approximately $15 \%$. The plasma conditions were; 5 mTorr pressure, $500 \mathrm{~W}$ ICP power, $22.5 \mathrm{sccm} \mathrm{Cl} \mathrm{Cl}_{2}, 2.5 \mathrm{sccm} \mathrm{H}_{2}, 5 \mathrm{sccm} \mathrm{Ar}, 25^{\circ} \mathrm{C}$ electrode temperature, and $150 \mathrm{~W}$ rf-power with a corresponding dc-bias of $-280 \pm 10 \mathrm{~V}$. Under these conditions the GaN etch rate was $\sim 6880 \AA / \mathrm{min}$ with highly anisotropic, smooth sidewalls. The vertical striations observed in the sidewall were due to striations in the photoresist mask which were transferred into the GaN feature during the etch. The sapphire substrate was exposed during the overetch period and showed significant pitting possibly due to defects in the substrate or growth process. With optimization of the masking process, these etch parameters may yield profiles and sidewall smoothness which improve etched facet laser performance.

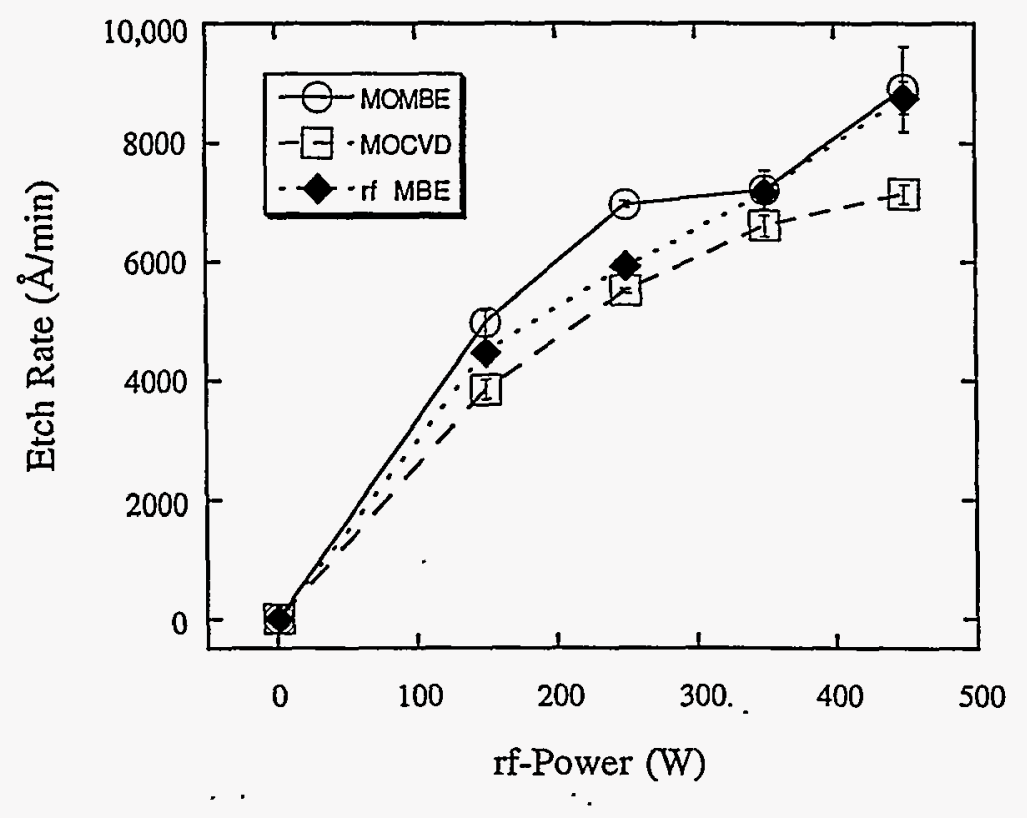

Figure 10. GaN etch rates as a function of if-Power for MO-MBE, MOCVD, and rf-MBE grown $\mathrm{GaN}$ in a $\mathrm{Cl}_{2} / \mathrm{H}_{2} / \mathrm{Ar}$ ECR-generated plasma. 


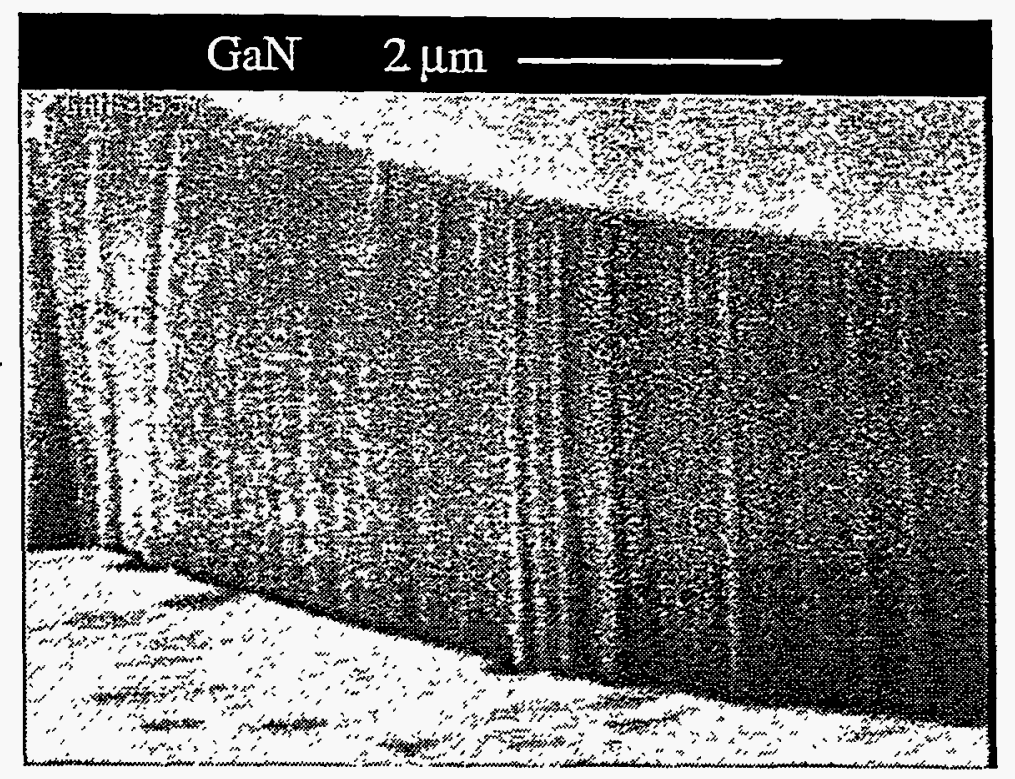

Figure 11. SEM micrograph of MOCVD GaN etched in an ICP-generated $\mathrm{Cl}_{2} / \mathrm{H}_{2} / \mathrm{Ar}$ plasma.

\section{CONCLUSIONS}

In summary, the utilization of high-density ECR and ICP chlorine-based plasmas has resulted in high rate $(>1 \mu \mathrm{m} / \mathrm{min})$, smooth, anisotropic etching of $\mathrm{GaN}$. The source of reactive $\mathrm{Cl}\left(\mathrm{Cl}_{2}\right.$, $\mathrm{BCl}_{3}, \mathrm{ICl}$, etc.) has several effects on the etch mechanism of $\mathrm{GaN}$ which must be identified and understood. Using $\mathrm{Cl}_{2}$-based plasmas typically resulted in relatively high concentrations of reactive $\mathrm{Cl}$ which increased the $\mathrm{GaN}$ etch rate. The addition of $\mathrm{H}_{2}, \mathrm{~N}_{2}$, or $\mathrm{SF}_{6}$ to $\mathrm{Cl}_{2}-$ or $\mathrm{BCl}_{3}-$ based plasmas appeared to effect the chemical removal the $\mathrm{N}$ atoms from the $\mathrm{GaN}$ or the concentration of reactive $\mathrm{Cl}$ in the plasma which directly correlated to the $\mathrm{GaN}$ etch rate. Very smooth pattern transfer was obtained for a wide range of plasma chemistries and conditions. The mechanism of breaking the GaN bonds appears to be critical and perhaps the rate limiting step in the etch mechanism. High-density plasmas provide improved $\mathrm{GaN}$ etch results due to a two step process directly related to the plasma flux. Initially the high-density plasmas increase the bond breaking mechanism allowing the etch products to form and then produce efficient sputter desorption of the etch products. ICP etching of the group-III nitrides in $\mathrm{Cl}_{2} / \mathrm{H}_{2}$ plasmas may yield profiles and sidewall smoothness which improve yield and performance of etched facet lasers. Identifying plasma conditions which maintain the stoichiometry of the as-grown films and minimize plasma-induced-damage are critical to the fabrication high performance group-III nitride devices and must be addressed.

\section{ACKNOWLEDGMENTS}

The authors would like to thank P. L. Glarborg and L. Griego for their technical support. This work was performed at Sandia National Laboratories supported by the U.S. Department of Energy under contract \# DE-AC04-94AL85000. Sandia is a multiprogram laboratory operated by Sandia Corporation, a Lockheed Martin Company, for the United States Department of Energy. 


\section{REFERENCES}

1. S. Nakamura, T. Mukai, M. Seno, and N. Iwasu, Jpn. J. Appl. Phys. 31, L139 (1992).

2. H. Amano, M. Kito, K. Hiramatsu, and I. Akasuki, Jpn. J. Appl. Phys. 28, L2112 (1989).

3. S. Nakamura, T. Mukai, and M. Senoh, Appl. Phys. Lett. 64, 1687 (9194).

4. S. Nakamura, M. Senoh, S. Nagahama, N. Iwasa, T. Yamada, T. Matsushito, H. Kiyoku, and U. Sugimoto, Jap. J. Appl. Phys. 35, L74 (1996).

5. J. C. Zolper, R. J. Shul, A. G. Baca, R. G. Wilson, S. J. Pearton, R. A. Stall, Appl. Phys. Letts. 68, 2273 (1996).

6. S. Strite and H. Morkoc, J. Vac. Sci. Technol. B 10, 1237 (1992).

7: 'M. A. Kahn, J. N. Kuzina, J. M. Van Hove, D. T. Olson, S. Krishnankutty, and R. M. Kolbas, Appl. Phys. Lett. 58, 526 (1991).

8. T. Matsuoka, T. Sasaki, and A. Katsui, Optoelectronic Devices and Technologies 5, 53 (1990).

9. M. A. Khan, A. Bhattarai, J. N. Kuznia, and D. T. Olson, Appl. Phys. Lett. 63, 1214 (1993).

10. I. Adesida, A. Mahajan, E. Andideh, M. Asif Khan, D. T. Olsen, and J. N. Kuznia, Appl. Phys. Lett. 63, 2777.

11. M. E. Lin, Z. F. Zan, Z. Ma. L. H. Allen, and H. Morkoc, Appl. Phys. Lett. 64, 887 (1994).

12. A. T. Ping, I. Adesida, M. Asif Khan, and J. N. Kuznia, Electron. Lett. 30, 1895 (1994).

13. H. Lee, D. B. Oberman, and J. S. Harris, Jr., J. Electron. Mat. 25, 835 (1996).

14. C. B. Vartuli, S. J. Pearton, J. W. Lee, J. Hong, J. D. MacKenzie, C. R. Abernathy, and R. J. Shul, Appl. Phys. Lett. 69, 1426 (1996).

15. C. B. Vartuli, S. J. Pearton, J. W. Lee, J. D. MacKenzie, C. R. Abernathy, and R. J. Shul, J. Vac. Sci. and Technol A, in press, (1997).

16. C. B. Vartuli, J. D. MacKenzie, J. W. Lee, C. R. Abernathy, S. J. Pearton, and R. J. Shul, J. Appl. Phys. 80, 3705 (1996).

17. S. J. Pearton, C. R. Abernathy, F. Ren, J. R. Lothian, P. W. Wisk, A. Katz, and C. Constantine, Semicond. Sci. Technol. 8, 310 (1993).

18. S. J. Pearton, C. R. Abernathy, and F. Ren, Appl. Phys. Lett. 64, 2294 (1994).

19. S. J. Pearton, C. R. Abernathy, and F. Ren, Appl. Phys. Lett. 64, 3643 (1994).

20. R. J. Shul, S. P Kilcoyne, M. Hagerott Crawford, J. E. Parmeter, C. B. Vartuli, C. R. Abernathy, and S. J. Pearton, Appl. Phys. Lett. 66, 1761 (1995).

21. L. Zhang, J. Ramer, J. Brown, K. Zheng, L. F. Lester, and S. D. Hersee, Appl. Phys. Lett. 68, 367 (1996).

22. R. J. Shul, A. J. Howard, S. J. Pearton, C. R. Abernathy, C. B. Vartuli, P. A. Barnes, and M. J. Bozack, J. Vac. Sci. Technol. B13, 2016 (1995).

23. G. F. McLane, L. Casas, S. J. Pearton, and C. R. Abernathy, Appl. Phys. Lett. 66, 3328 (1995).

24. I. Adesida, A. T. Ping, C. Youtsey, T. Dow, M. Asif Khan, D. T. Olson, and J. N. Kuzina, Appl. Phys. Lett 65, 889 (1994).

25. R. J. Shul, G. B. McClellan, S. J. Pearton, C. R. Abernathy, C. Constantine, and C. Barratt, Electron. Lett. 32, 1408 (1996).

26. R. J..Shul, G. B. McClellan, S. A. Casalnuovo, D. J. Rieger, S. J. Pearton, C. Constantine, C. Barratt, R. F. Karlicek, Jr., C. Tran, and M. Schurman, Appl. Phys. Lett. 69, 1119 (1996).

27. H. P. Gillis, D. A. Choutov, and K. P. Marlin, JOM, 50 (1996).

28. C. R. Abernathy, J. Vac. Sci. Technol. A 11, 869 (1993).

29. C. Yuan, T. Salagaj, A. Gurary, P. Zawadzki, C. S. Chern, W. Kroll, R. A. Stall, Y. Li, M. Schurman, C.-Y. Hwang, W. E. Mayo, Y. Lu, S. J. Pearton, S. Krishnankutty, and R. M. Kolbas, J. Electrochem. Soc. 142, L163 (1995).

30. S. J. Pearton and R. J. Shul, "III-Nitrides", Academic Press, in press.

31. R. J. Shul, G. B. McClellan, R. D. Briggs, D. J. Rieger, S. J. Pearton, C. R. Abernathy, J. W. Lee, C. Constantine, and C. Barratt, J. Vac. Sci. and Technol A, in press, (1996).

32. F. Ren, J. R. Lothian, J. M. Kuo, W. S. Hobson, J. Lopata, J. A. Caballero, S. J. Pearton, and M. W. Cole, J. Vac. Sci. Technol. B14, 1 (1995). 